IZA DP No. 9568

The Caregiving Responsibilities of Retirees:

What Are They and How Do They Affect Retirees' Well-being?

Charlene M. Kalenkoski

Eakamon Oumtrakool

December 2015 


\title{
The Caregiving Responsibilities of Retirees: What Are They and How Do They Affect Retirees' Well-being?
}

\author{
Charlene M. Kalenkoski \\ Texas Tech University \\ and IZA
}

Eakamon Oumtrakool

Texas Tech University

\section{Discussion Paper No. 9568 \\ December 2015}

\author{
IZA \\ P.O. Box 7240 \\ 53072 Bonn \\ Germany \\ Phone: +49-228-3894-0 \\ Fax: +49-228-3894-180 \\ E-mail: iza@iza.org
}

\begin{abstract}
Any opinions expressed here are those of the author(s) and not those of IZA. Research published in this series may include views on policy, but the institute itself takes no institutional policy positions. The IZA research network is committed to the IZA Guiding Principles of Research Integrity.

The Institute for the Study of Labor (IZA) in Bonn is a local and virtual international research center and a place of communication between science, politics and business. IZA is an independent nonprofit organization supported by Deutsche Post Foundation. The center is associated with the University of Bonn and offers a stimulating research environment through its international network, workshops and conferences, data service, project support, research visits and doctoral program. IZA engages in (i) original and internationally competitive research in all fields of labor economics, (ii) development of policy concepts, and (iii) dissemination of research results and concepts to the interested public.
\end{abstract}

IZA Discussion Papers often represent preliminary work and are circulated to encourage discussion. Citation of such a paper should account for its provisional character. A revised version may be available directly from the author. 
IZA Discussion Paper No. 9568

December 2015

\begin{abstract}
The Caregiving Responsibilities of Retirees: What Are They and How Do They Affect Retirees' Well-being?*

Using data from the 2010 and 2012 American Time Use Surveys (ATUS) and the associated Well-being Modules, this paper examines how caregiving affects the well-being of retirees who are caregivers. Different caregiving activities are examined, including caring for household children, caring for non-household children, caring for household adults, and caring for non-household adults. Different aspects of well-being are examined, including how meaningful respondents find their activities and how happy, sad, tired, in pain, and stressed their activities make them. The results show that, controlling for selection into caregiving, most caregiving negatively affects the well-being of retirees. This suggests that policies that remove some of the caregiving burden from retirees would increase their well-being.
\end{abstract}

JEL Classification: D10, D13

Keywords: caregiving, well-being, retirement, time use

Corresponding author:

Charlene M. Kalenkoski

Department of Personal Financial Planning

Texas Tech University

1301 Akron Avenue

Box 41210

Lubbock, TX 79409-1210

USA

E-mail: charlene.kalenkoski@ttu.edu

\footnotetext{
* The authors thank Das Debanik and Yuanshan Cheng for research assistance.
} 


\section{Introduction:}

Retirees no longer have the requirement to spend time in market work. However, they may have increased other responsibilities such as caring for an elderly parent, spouse, or grandchildren. Johnson and Schaner (2005) report that nearly $40 \%$ of people aged 55 and older spent time caring for family members in 2002, and that grandchild care was the most prevalent, followed by parental care, spousal care, and child care. They also report that about $7 \%$ of adults aged 55 and older cared for multiple generations of relatives and that the likelihood of providing spousal care increases with age. Ellis and Simmons (2014) report that, in 2012, about 2.7 million grandparents had primary responsibility for their grandchildren under 18 years of age who were living with them. The U.S. Bureau of Labor Statistics (2015) also recently released a descriptive report based on the 2013-2014 American Time Use Surveys (ATUS) that showed the importance of elder care by older Americans.

Given the substantial amount of caregiving that has been reported by this group, it is important to examine whether and how caregiving affects the well-being of the caregiver. Economic theory predicts that a person voluntarily will undertake caregiving if it provides utility, i.e., happiness or satisfaction. However, caregiving may be involuntary due to monetary constraints, cultural norms, or legal responsibilities. If this is the case, caregiving responsibilities act as a constraint on a person's utility maximization, reducing his or her choice set and decreasing his or her utility. The existing literature has provided some evidence as to whether caregiving improves or decreases well-being, and much of it is negative. Pinquart and Sorenson (2003) performed a meta-analysis integrating findings from 84 articles that examined differences in the well-being of caregivers and non-caregivers to frail older adults. They found that caregivers had higher levels of stress and depression and lower levels of subjective well-being, physical health, and self-efficacy than non-caregivers. Vitaliano et al. (2003) also performed a metaanalysis, but theirs covered studies of caregivers of dementia patients. They found that these caregivers exhibited a slightly higher risk for health problems than non-caregivers. Subsequently, Pinquart and Sorenson (2004) performed another meta-analysis, this time focusing on caregivers' subjective well- 
being. In this study, they continued to find negative effects of caregiving but, unlike the other studies, did find some positive effects.

A limitation of all these studies, however, is that they have focused on a narrow group of caregivers, those caring for frail older adults or adults suffering from dementia, and thus their results may not apply to caregivers of other adults or children. This study examines caregiving for any adult, regardless of whether or not the recipient of care is physically frail or suffers from dementia, in order to determine the effects of caregiving on caregivers more generally ${ }^{1}$. It also distinguishes between care for household adults and care for non-household adults because the level and type of care may differ depending on whether the caregivers co-reside with the recipient of care. Because this study focuses on retirees, it also examines caregiving for children, separately by whether or not the children live with their caregiver, as many grandchildren often are cared for by their grandparents. Finally, while many studies of caregivers rely on small samples, this study uses the large, nationally representative ATUS and its Well-being Modules (WBM).

\section{Data:}

The data used in this paper come from the 2010 and 2012 ATUS and WBM. ATUS respondents were chosen from participants in the Current Population Survey (CPS). After completion of the CPS, one respondent aged 15 or older per household was selected for the ATUS. Each respondent to the ATUS answered some survey questions and completed a 24-hour time diary, where the diary covered the period between 4 a.m. on the day before the interview and 4 a.m. on the day of the interview. Respondents provided information on the activities they performed on that day, at what times, and with whom. From this ATUS sample were drawn 3,475 retirees, where retirees are defined as individuals who, at the time of the survey, were at least 50 years old; were not currently in the labor force; did not report any minutes spent on work, work-related activities, or travel related to work on their diary day; and reported being

\footnotetext{
${ }^{1}$ The ATUS does not identify recipients of care or their health status.
} 
retired or that they didn't want a job. ${ }^{2}$ Information on these retirees' gender, marital status, race, Hispanic ethnicity, education, region of residence, and household composition (number of adults and children in the household) was obtained from either the ATUS or CPS survey while information on time spent caring for household adults, household children, non-household adults, and non-household children was obtained from the ATUS time diary. Given that the data are a pooled cross-section, a year dummy is included for 2012 and survey weights are used in all analyses.

Figure 1 shows that just over $20 \%$ of retirees provided some sort of caregiving. Figure 2 shows who received this care. $35 \%$ of retiree caregivers provided care for non-household adults only, $26 \%$ provided care for non-household children only, $25 \%$ provided care for household adults only, $7 \%$ provided care for household children only, and 7\% provided care for more than one type of recipient.

All ATUS respondents in 2010 and 2012 were selected for the WBM. The WBM collected information for each respondent on three randomly selected activities he or she performed on his or her diary day as recorded in the ATUS. ${ }^{3}$ Random selection was made from reported activities lasting for at least 5 minutes. Sleeping, grooming, personal activities, don't know/can't remember, and refusal/none of your business were not eligible for selection. For each of the selected activities, six questions related to quality of life were asked, including five affect questions and one question about how meaningful the activity was. The affect questions included how happy, tired, stressed, sad, and in pain an activity made the respondent feel, and respondents were asked to answer these questions on a scale ranging from 0 to 6 , where 0 meant not at all happy, tired, stressed, sad, or in pain and 6 meant very happy, tired, stressed, sad, or in pain. Answers to the affect questions ranged from 0 to 6 , with 0 being the lowest level and 6 being

\footnotetext{
${ }^{2}$ The Disability and Use of Time Supplement (DUST) to the Panel Study of Income Dynamics (PSID) is an alternative nationally representative data set that can be used to examine the caregiving of Americans aged 50 and older. However, using these data would result in a dramatically reduced sample size.

${ }^{3}$ In 2010, and part of 2013, eligible activities that took place near the end of the diary day were underrepresented due to an error in randomization. However, an annual activity-level statistical weight is provided with the ATUS WB data that corrects for this. This paper utilizes this weight.
} 
the highest level. The meaningful question also required a response in the range of 0 to 6 , with 0 indicating not meaningful at all and 6 indicating very meaningful.

\subsection{Dependent Variables:}

Using these three activity-level responses, we were able to create average measures of happiness, tiredness, stress, sadness, pain, and meaningfulness for each respondent on his or her diary day. For example, for each respondent, the average happiness measure was calculated using the following formula:

$$
\text { Respondent Happiness }=\text { Happy }_{1} * \mathrm{~W}_{1}+\mathrm{Happy}_{2} * \mathrm{~W}_{2}+\mathrm{Happy}_{3} * \mathrm{~W}_{3}
$$

where Happy ${ }_{1}$ is the happy rating for the first randomly selected activity, Happy 2 is the happy rating for the second randomly selected activity, Happy ${ }_{3}$ is the happy rating for the third randomly selected activity, $\mathrm{W}_{1}$ is the weight assigned to activity one, $\mathrm{W}_{2}$ is the weight assigned to activity two, and $\mathrm{W}_{3}$ is the weight assigned to activity three. The three weights sum to one. The weights are provided in the WBM and are constructed so that activities of longer duration are assigned more weight. The average tiredness, stress, sadness, pain, and meaningfulness measures were constructed in a similar manner. The resulting scores for each affect are continuous variables that range from 0 to $6 .{ }^{4}$

\subsection{Explanatory Variables:}

The key explanatory variables included as regressors in the well-being models are indicators for the four types of caregiving that are examined in this paper: caring for household adults, caring for nonhousehold adults, caring for household children, and caring for non-household children. In addition, several control variables are included both in the well-being models and in the caregiving probit selection

\footnotetext{
${ }^{4}$ Alternative well-being measures that have been used in the literature include the U-index and net affect (Kahneman and Krueger, 2006). However, these measures are based on activity-level rather than respondent-level analysis and cannot be used here.
} 
models. These are standard controls and include age, gender, marital status, race, ethnicity, educational level, diary day, number of adults in the household, and number of children in the household. These variables control for differential preferences toward caregiving across demographic groups (i.e., cultural norms) as well as economic circumstances and constraints.

\subsection{Instrumental Variables:}

Additional data were merged with the combined ATUS and WBM data at the state level, the state-year level and the year-region level. ${ }^{5}$ These are used as instrumental variables in the analysis and include some measures of the cost, availability, and quality of purchased care. Cost, availability, and quality of care measures affect a person's decisions regarding how much caregiving time to spend, as purchased care is a substitute for one's own time. However, they should not affect an individual's wellbeing directly.

The state-level instruments came from the publication "2012 Across the States: Profiles of LongTerm Services and Supports" (Houser et al. 2012) and include nursing facility service expenditures (in $\$ 1000$ s), community living congregate and home delivered meal expenditures (in billions of dollars), the median hourly wage of personal and home care aides, the percent of people aged 75 and over living alone, the percent of people aged 65 and over living in households with someone under the age of 18, the percent of residents with Medicare as the primary payer, the percent of nursing facilities visited by an ombudsman at least quarterly, the ratio of the economic value of family caregiving to Medicaid long-term care spending, the number of private long-term care insurance policies in effect per 1000 people aged 40 and above, the number of participants in personal care services and home health per 1000, the number of assisted living and residential care facilities per 1000 people aged 65 and above, the number of people receiving the administration for community living congregate meals per 1000 people aged 65 and above, the number of people receiving the administration for community living home delivered meals per 1000

\footnotetext{
${ }^{5}$ This study uses WBM data from 2010 and 2012. Although 2013 WBM data are available, the lack of state-level data for this year limits us to analysis of 2010 and 2012 WBM data only.
} 
people aged 65 and above, and the number of registered nurse hours per day. The state's ranking on longterm care services and supports system performance from the 2014 report, "2014 Raising Expectations: A State Scorecard on Long-Term Services and Supports for Older Adults, People with Physical Disabilities, and Family Caregivers," jointly produced by the AARP, The Commonwealth Fund, and the SCAN Foundation, is also included as a state-level instrument.

The state-year-level measures used in this paper include the average annual assisted living facility cost and the average annual private-room nursing home cost, obtained from Genworth's 2010 and 2012 Cost of Care Surveys. They also include the average hourly home health aide service cost and daily adult day services cost from the 2010 and 2012 Market Surveys of Long-Term Care Costs produced by the Mature Market Institute (MMI), MetLife's research organization.

Finally, one variable at the year-region level was included. This is the percentage of people with at least one activity of daily living (ADL) limitation and was obtained from the 2014 Health System Measurement Project.

Table 1 provides descriptive statistics for all of the variables used in the analysis. On average, retirees appear to be reasonably happy (average happy score of 4.5 out of 6 ) and deriving meaning from their activities (average meaningfulness score of 4.5 out of 6 ). Retirees also report low levels of sadness, tiredness, pain, and stress (average scores of $0.6,1.8,1.2$, and 0.9 , respectively). On the diary day, $6.1 \%$ of retirees reported caring for household adults, $8.3 \%$ reported caring for non-household adults, $1.6 \%$ reported caring for household children, and 6.2\% reported caring for non-household children.

Regarding the personal characteristics of the retirees in the sample, their average age is $72,60 \%$ are female, $62 \%$ are married, $87 \%$ are white, $5 \%$ are Hispanic, $84 \%$ have at least a high school education, and $24 \%$ have at least a college degree. The average number of adults per retiree household is 1.86 , and the average number of children per retiree household is 0.07 .

Table 2 shows how the well-being scores differ by whether or not a retiree participates in the different categories of care. Retirees who care for household children or adults report higher levels of stress than those who do not. Retirees who care for non-household adults report lower levels of sadness 
and pain. Retirees who care for non-household children report higher levels of happiness and meaning and lower levels of sadness, pain, and stress. From these descriptive statistics it appears that retirees who care for adults or children inside their household have lower levels of well-being than retirees who do not, but that those who care for adults or children outside their household have higher levels of well-being than those who do not. This is consistent with the idea that caregiving for those outside of one's household is more of a voluntary action than caregiving for those inside one's household. However, it may be the case that those with higher well-being to begin with self-select into caring for others outside the household. Therefore, the model presented in this paper accounts for self-selection into caregiving activities.

\section{Model:}

For each measure of average daily well-being, the following system of equations is estimated via Limited Information Maximum Likelihood (LIML):

$$
\begin{gathered}
\mathrm{ADWB}_{\mathrm{i}}=\alpha_{0}+\alpha_{1} \mathrm{C}_{\mathrm{HAi}}+\alpha_{2} \mathrm{C}_{\mathrm{NAi}}+\alpha_{3} \mathrm{C}_{\mathrm{HCi}}+\alpha_{4} \mathrm{C}_{\mathrm{NCi}}+\alpha_{2} \mathrm{X}_{\mathrm{i}}+\mathrm{a}_{\mathrm{i}} \\
\mathrm{C}_{\mathrm{HAi}} *=\beta_{0}+\beta_{1} \mathrm{X}_{\mathrm{i}}+\beta \mathrm{W}_{\mathrm{i}}+\mathrm{b}_{\mathrm{i}} \\
\mathrm{C}_{\mathrm{HAi}}=1 \text { if } \mathrm{C}_{\mathrm{HAi}} *>0,=0 \text { otherwise } \\
\mathrm{C}_{\mathrm{NAi}} *=\gamma_{0}+\gamma_{1} \mathrm{X}_{\mathrm{i}}+\gamma \mathrm{W}_{\mathrm{i}}+\mathrm{c}_{\mathrm{i}} \\
\mathrm{C}_{\mathrm{NAi}}=1 \text { if } \mathrm{C}_{\mathrm{NAi}} *>0,=0 \text { otherwise } \\
\mathrm{C}_{\mathrm{HCi}} *=\rho_{0}+\rho_{1} \mathrm{X}_{\mathrm{i}}+\rho \mathrm{W}_{\mathrm{i}}+\mathrm{d}_{\mathrm{i}} \\
\mathrm{C}_{\mathrm{HCi}}=1 \text { if } \mathrm{C}_{\mathrm{HCi}} *>0,=0 \text { otherwise }
\end{gathered}
$$




$$
\mathrm{C}_{\mathrm{NCi}}=1 \text { if } \mathrm{C}_{\mathrm{NCI}} *>0,=0 \text { otherwise }
$$

Equation (1) is a continuous regression model in which $\mathrm{ADWB}_{\mathrm{i}}$ is the average daily well-being measure for person i (for example, person i's daily happy score); $\mathrm{C}_{\mathrm{HAi}}, \mathrm{C}_{\mathrm{NAi}}, \mathrm{C}_{\mathrm{HCi}}$, and $\mathrm{C}_{\mathrm{NCi}}$ are indicators for whether the person cared for a household adult, a non-household adult, a household child, and a nonhousehold child, respectively, on the diary day; $X_{i}$ is a vector of person-level characteristics; $a_{i}$ is the error term, and the alphas are the coefficients to be estimated. Equation (1) is modeled as a continuous regression given that the scores can take any values between 0 and 6 (i.e., they are not limited to integers). Equations (2), (3), (4), and (5) are probit models where $\mathrm{C}_{\mathrm{HAi}}{ }^{*}, \mathrm{C}_{\mathrm{NAi}}{ }^{*}, \mathrm{C}_{\mathrm{HCi}}{ }^{*}$, and $\mathrm{C}_{\mathrm{NCi}}{ }^{*}$ are the relevant latent variables; $\mathrm{W}$ is the vector of instrumental variables (variables that affect the caregiving indicators but not well-being directly -at least four are needed for identification); $\mathrm{b}_{\mathrm{i}}, \mathrm{c}_{\mathrm{i}}, \mathrm{d}_{\mathrm{i}}$, and $\mathrm{e}_{\mathrm{i}}$ are the errors to be estimated; and the betas, gammas, rhos, and lambdas are the parameters to be estimated. Estimating these equations jointly improves the efficiency of the estimates over any two-stage instrumental variables approach.

If a person engages in caregiving voluntarily, that person likely derives utility (increased wellbeing) from the activity. However, if caregiving is involuntary, the caregiver instead may experience disutility, that is, suffer from decreased well-being. Because we can't know an individual caregiver's private motivation for caregiving, it cannot be said a priori whether the proposed study will find negative or positive effects of any of the caregiving measures on any of the well-being measures. That is, we cannot a priori assign positive or negative signs to $\alpha_{1}, \alpha_{2}, \alpha_{3}$, or $\alpha_{4}$. The existing literature has provided mostly negative evidence as to whether caregiving improves or decreases well-being. However, this paper examines whether this extends to broader measures of care and a nationally representative sample.

\section{Results:}

Table 3 shows the estimated effects of each of the different types of caregiving activities on the "negative" daily well-being measures, the tired, pain, sad, and stress scores. Caring for household adults 
increases the pain score by 3.0 and the stress score by 1.9. Caring for non-household adults increases the tired score by 2.8 , and the sad score by 1.7 . These are very large effects given that the average scores provided for these wellbeing measures in Table 1 are 1.2 for pain, 0.9 for stress, 1.8 for tired, and 0.6 for sad. Caring for household children does not appear to affect any of these "negative" well-being measures, but caring for non-household children has large effects on well-being. Caring for non-household children increases the tired score by 2.2 , the sad score by 1.6 , and the stress score by 2.1 , but caring for nonhousehold children does reduce the pain score by 0.7 .

The relationships among several of the control variables and these "negative" well-being measures are also significant. Being female is associated with a higher tired score. Being married reduces pain, sadness, and stress and so does a greater level of education. An additional adult living in a retiree's household increases the tired score. An additional child living in a retiree's household increases the pain score.

Table 4 shows the estimated effects of the different types of caregiving on the "positive" wellbeing measures, the meaningful and happy scores. Caring for household adults, caring for non-household adults, and caring for non-household children decrease the meaningful score by $2.1,1.7$, and 1.9, respectively. In addition, caring for non-household adults and caring for non-household children reduce the happy score by 2.1 and 1.6, respectively, while caring for household children does not appear to affect either score. Regarding the control variables, female retirees have higher average meaningful and happy scores than males, married retirees have greater meaningful and happy scores than those who are unmarried, and Hispanics have higher meaningful and happy scores than non-Hispanics.

Table A1 shows the estimated coefficients and standard errors for the caregiving probits associated with the tired model. The significance of the instrumental variables can be viewed in this table. In each of these probits there are multiple instruments that are highly individually significant. In addition, the entire set of instruments is highly jointly significant in many cases (see the adjusted Wald test results at the bottom of the table). The caregiving probits for the other well-being models are similar and are available upon request from the authors. 


\section{Sensitivity Analysis: All People over Age 50}

Are the results in this paper generalizable to all adults over age 50 or do they just apply to retirees? Tables 5 and 6 show the results of re-estimating the well-being models on a broader sample of adults aged 50 and older, regardless of retirement status. The results are similar to those for the retiree sample. However, for the broader sample, care for household children increases the sad score by 0.5 and the stress score by 0.7 . If the diary day is a weekend, they have lower tired, sad, and stress scores and higher happy scores. A dummy variable for "retired" is included in these regressions and shows that being retired reduces tired, sad, and stress scores compared to not being retired. Taken together, these sensitivity analysis results suggest that, while retirement itself is good for well-being, retirees still suffer the same negative effects from caring for others as do non-retired individuals, even though they have more time.

\section{Conclusion:}

This paper used data from the 2010 and 2012 ATUS and WBM to examine how caring for adults and children, both inside and outside the household, affects the well-being of retirees. Different aspects of well-being were examined and the results showed that most caregiving negatively affects the wellbeing of retirees. Thus, policies that remove some of the caregiving burden from retirees would increase their well-being. 


\section{References}

AARP, The Commonwealth Fund, and The SCAN Foundation (2014). "2014 Raising Expectations: A State Scorecard on Long-Term Services and Supports for Older Adults, People with Physical Disabilities, and Family Caregivers," http://www.aarp.org/home-family/caregiving/info2014/raising-expectations-2014-AARP-ppi-health.html. Accessed 8/17/14.

Ellis, Renee R. and Simmons, Tavia (2014). "Coresident Grandparents and Their Grandchildren: 2012," https://www.census.gov/content/dam/Census/library/publications/2014/demo/p20-576.pdf. Accessed 9/06/15.

Genworth Financial (2010). "Genworth 2010 Cost of Care Survey," https://www.genworth.com/dam/Americas/US/PDFs/Consumer/corporate/coc_10.pdf. Accessed $8 / 17 / 14$.

(2012). "Genworth 2012 Cost of Care Survey,"

https://www.genworth.com/dam/Americas/US/PDFs/Consumer/corporate/coc_12.pdf. Accessed $8 / 22 / 14$

Houser, Ari; Fox-Grage, Wendy; and Ujvari, Kathleen (2012). “2012 Across The States: Profiles of Long-Term Services and Supports," http://www.aarp.org/home-garden/livable-communities/info09-2012/across-the-states-2012-profiles-of-long-term-services-supports-AARP-ppi-ltc.html.

Accessed 8/19/14.

Health System Measurement Project (2014). Percentage of People with at Least One Activities of Daily Living (ADL) Limitation. Retrieved from https://healthmeasures.aspe.hhs.gov/measure/35. Accessed 8/18/14.

Johnson, Richard W. and Simone G. Schaner (2005). “Many Older Americans Engage in Caregiving Activities," The Retirement Project: Perspectives on Productive Aging, No. 3, pp. 1-5.

Kahneman, D., \& Krueger, A. B. (2006). Developments in the Measurement of Subjective Well-Being. Journal of Economic Perspectives, 20(1), 3-24.

Mature Market Institute (2010). "Market Survey of Long-Term Care Costs," 
https://www.metlife.com/assets/cao/mmi/publications/studies/2010/mmi-2010-market-surveylong-term-care-costs.pdf. Accessed 8/18/14.

(2012). "Market Survey of Long-Term Care Costs,"

https://www.metlife.com/assets/cao/mmi/publications/studies/2012/studies/mmi-2012-marketsurvey-long-term-care-costs.pdf. Accessed 8/18/14.

Pinquart, Martin and Silvia Sorensen (2003). "Differences between Caregivers and Noncaregivers in Psychological Health and Physical Health: A Meta-Analysis," Psychology and Aging, Vol. 18, No. 2, pp. 250-267.

(2004). “Associations of Caregiver Stressors and Uplifts with Subjective Well-being and

Depressive Mood: A Meta-analytic Comparison," Aging and Mental Health, Vol. 8, No. 5, pp. $438-449$.

U.S. Bureau of Labor Statistics (2014). “American Time Use Survey (ATUS) Data Dictionary: 2010 and 2012 Well-being Module Data: Variables Collected in the ATUS Well-being Module: May 2014," http://www.bls.gov/tus/wbmintcodebk.pdf. Accessed 5/20/14.

(2015). "Unpaid Eldercare in the United States - 2013-2014 Data from the American Time Use Survey," News Release 9/23/15.

Vitaliano, Peter P.; Zhang, Jianping; and James M. Scanlan (2003). "Is Caregiving Hazardous to One's Physical Health? A Meta-Analysis,” Psychological Bulletin, Vol. 129, No. 6, pp. 946-972. 
Figure 1. Percentage of Retirees Providing Caregiving

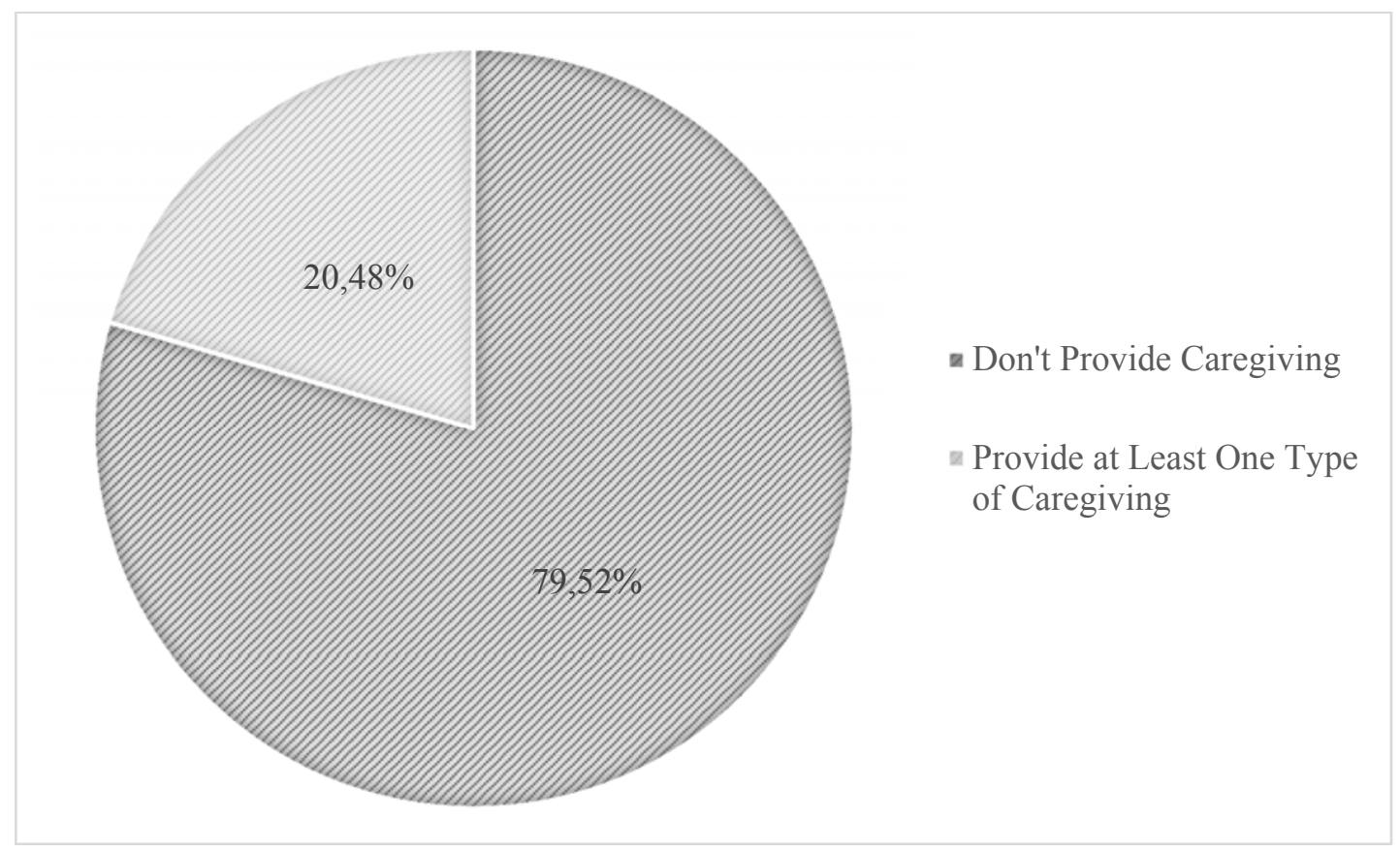

2010 and 2012 American Time Use Survey (ATUS) and its Well-being Modules (WBM). Number of observations $=3,475$. Survey weights were used. 
Figure 2. Types of Caregiving Provided by Retirees

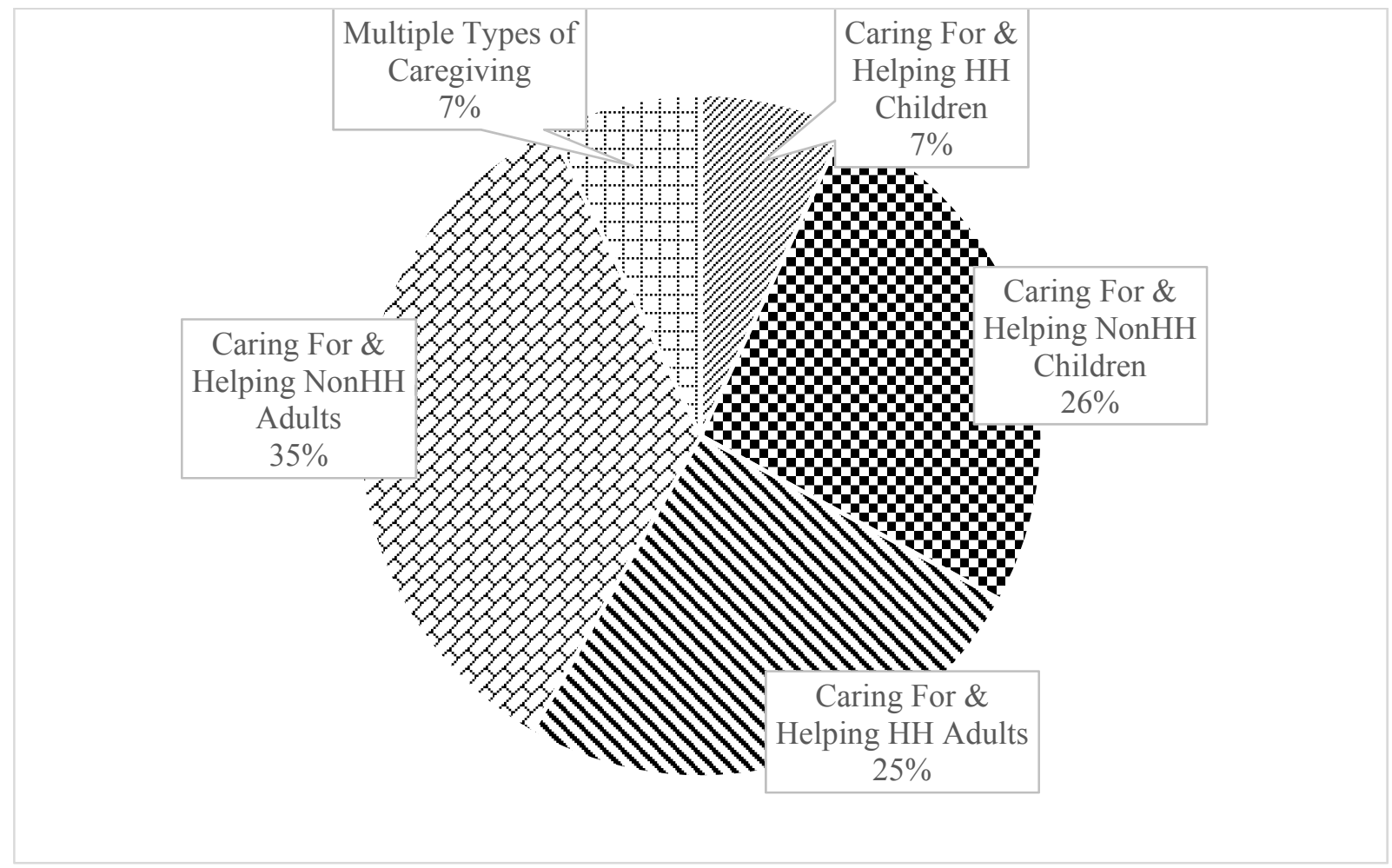

2010 and 2012 American Time Use Survey (ATUS) and its Well-being Modules (WBM). Number of observations $=648$. Survey weights were used. 
Table 1. Descriptive Statistics for the Sample of Retirees

\begin{tabular}{|c|c|c|c|}
\hline Dependent Variables & Mean & Min. & Max. \\
\hline \multicolumn{4}{|l|}{ Well-Being Measures } \\
\hline Happy measure & 4.5350 & 0 & 6 \\
\hline Meaningful measure & 4.4786 & 0 & 6 \\
\hline Sad measure & 0.6437 & 0 & 6 \\
\hline Tired measure & 1.7587 & 0 & 6 \\
\hline Pain measure & 1.1653 & 0 & 6 \\
\hline Stress measure & 0.9191 & 0 & 6 \\
\hline Independent Variables & & Mean & Std. Dev. \\
\hline \multicolumn{4}{|l|}{ Caregiving (Indicator Variables) } \\
\hline Care for household adults & & 0.0605 & 0.2499 \\
\hline Care for non-household adults & & 0.0825 & 0.2884 \\
\hline Care for household children & & 0.0156 & 0.1297 \\
\hline Care for non-household children & & 0.0617 & 0.2522 \\
\hline (а) & & 72.0359 & 8.1685 \\
\hline Female & & 0.5972 & 0.5140 \\
\hline Married & & 0.6156 & 0.5098 \\
\hline White & & 0.8714 & 0.3509 \\
\hline Hispanic & & 0.0505 & 0.2294 \\
\hline \multicolumn{4}{|l|}{ Education } \\
\hline Less than high school & & 0.1589 & 0.3831 \\
\hline High school & & 0.3852 & 0.5100 \\
\hline Some college & & 0.2207 & 0.4346 \\
\hline College & & 0.1448 & 0.3687 \\
\hline Advanced education & & 0.0905 & 0.3006 \\
\hline \multicolumn{4}{|l|}{ Region } \\
\hline Northeast & & 0.1916 & 0.4124 \\
\hline Midwest & & 0.2524 & 0.4552 \\
\hline South & & 0.3700 & 0.5060 \\
\hline West & & 0.1860 & 0.4078 \\
\hline \multicolumn{4}{|l|}{ Diary day } \\
\hline Weekday & & 0.7144 & 0.4733 \\
\hline Weekend & & 0.2856 & 0.4733 \\
\hline Number of adults in the household & & 1.8621 & 0.7436 \\
\hline Number of children in the household & & 0.0723 & 0.3842 \\
\hline
\end{tabular}

2010 and 2012 American Time Use Survey (ATUS) and its Well-being Modules (WBM). Number of observations is 3,475 . Survey weights were used. 
Table 1. Descriptive Statistics for the Sample of Retirees (continued)

\begin{tabular}{|c|c|c|}
\hline Instrumental Variables & Mean & Std. Dev. \\
\hline \multicolumn{3}{|l|}{ By Year and State: } \\
\hline Assisted Living Facility Annual Rate (in $\$ 1,000$ s) ${ }^{1}$ & $\$ 39.1476$ & $\$ 7.6358$ \\
\hline Nursing Home Annual Rate (Private Room) (in $\$ 1,000 \mathrm{~s})^{1}$ & $\$ 82.9080$ & $\$ 20.0978$ \\
\hline Home Health Aide Services Hourly Rate (in $\$ 1,000$ s) ${ }^{2}$ & $\$ 0.0206$ & $\$ 0.0028$ \\
\hline Adult Day Services Daily Rate (in $\$ 1,000 \mathrm{~s})^{2}$ & $\$ 0.0669$ & $\$ 0.0165$ \\
\hline \multicolumn{3}{|l|}{ By Year and Region: } \\
\hline Percent of People with at Least One Activities of Daily Living Limitation ${ }^{3}$ & 0.0185 & 0.0008 \\
\hline \multicolumn{3}{|l|}{ By State: } \\
\hline Nursing Facility Service Expenditure (in $\$ 1,000 \mathrm{~s})^{4}$ & $\$ 29.1867$ & $\$ 6.1359$ \\
\hline $\begin{array}{l}\text { Total Administration for Community Living (ACL) Congregate and Home Delivered Meal Expenditures (in } \\
\text { billions of } \$)^{4}\end{array}$ & $\$ 0.0357$ & $\$ 0.0172$ \\
\hline Median Hourly Wage of Personal and Home Care Aides ${ }^{4}$ & $\$ 9.5628$ & $\$ 0.9393$ \\
\hline Percent of People Age 75 and Over Living Alone ${ }^{4}$ & 0.3381 & 0.0288 \\
\hline Percent of People Age 65 and Over Living in Households with Someone under Age $18^{4}$ & 0.0661 & 0.0253 \\
\hline Percent of Residents with Medicare as Primary Payer ${ }^{4}$ & 0.1488 & 0.0308 \\
\hline Percent of Nursing Facilities Visited by Ombudsman at Least Quarterly ${ }^{4}$ & 0.7632 & 0.2575 \\
\hline State Ranking on Long-Term Services and Supports (LTSS) System Performance ${ }^{5}$ & 27.8577 & 15.1662 \\
\hline Ratio of the Economic Value of Family Caregiving to Medicaid Long-Term Care Spending ${ }^{4}$ & 4.5140 & 1.8370 \\
\hline Number of Private Long-Term Care Insurance Policies in Effect, per 1000, Age 40 and Above ${ }^{4}$ & 45.3549 & 23.0388 \\
\hline Number of Participants in Personal Care Services (PCS) and Home Health, per 1,000 & 5.3934 & 4.2769 \\
\hline Number of Assisted Living and Residential Care Facilities, per 1000 Age 65 and Above ${ }^{4}$ & 1.5513 & 1.9800 \\
\hline $\begin{array}{l}\text { Number of People Receiving the Administration for Community Living (ACL) Congregate Meals, per } 1000 \text { Age } \\
65 \text { and Above } \\
\text { Number of People Receiving Administration for Community Living (ACL) Home Delivered Meals, per } 1000\end{array}$ & 43.3912 & 30.1347 \\
\hline Age 65 and Above ${ }^{4}$ & 22.5483 & 11.8032 \\
\hline RN hours per day ${ }^{4}$ & 0.6490 & 0.1299 \\
\hline
\end{tabular}

Number of observations is 3,475. Sources: ' Genworth 2010 and 2012 Cost of Care Survey. ${ }^{2} 2010$ and 2012 Market Survey of Long-Term Care Costs. ${ }^{3}$ Health System Measurement Project. ${ }^{4} 2012$ Across The States: Profiles of Long-Term Services and Supports. ${ }^{5} 2014$ Raising Expectations: A State Scorecard on Long-Term Services and Supports for Older Adults, People with Physical Disabilities, and Family Caregivers. 
Table 2. Retirees’ Average Daily Well-being Scores by Caregiving Status

\begin{tabular}{|c|c|c|c|c|c|c|c|c|c|c|c|c|}
\hline $\begin{array}{c}\text { Well-being } \\
\text { Scores }\end{array}$ & $\begin{array}{c}\text { Care for } \\
\text { Household } \\
\text { adults }\end{array}$ & $\begin{array}{c}\text { Do not } \\
\text { care for } \\
\text { household } \\
\text { adults }\end{array}$ & Sig. & $\begin{array}{c}\text { Care for } \\
\text { non- } \\
\text { household } \\
\text { adults }\end{array}$ & $\begin{array}{l}\text { Do not } \\
\text { care for } \\
\text { non- } \\
\text { household } \\
\text { adults }\end{array}$ & Sig. & $\begin{array}{l}\text { Care for } \\
\text { household } \\
\text { children }\end{array}$ & $\begin{array}{l}\text { Do not } \\
\text { care for } \\
\text { household } \\
\text { children }\end{array}$ & Sig. & $\begin{array}{l}\text { Care for } \\
\text { non- } \\
\text { household } \\
\text { children }\end{array}$ & $\begin{array}{l}\text { Do not } \\
\text { care for } \\
\text { non- } \\
\text { household } \\
\text { children }\end{array}$ & Sig. \\
\hline Happy Score & 4.4839 & 4.5380 & & 4.6913 & 4.5206 & & 4.4252 & 4.5365 & & 4.8419 & 4.5145 & * \\
\hline Meaningful Score & 4.5680 & 4.4728 & & 4.5202 & 4.4748 & & 4.5395 & 4.4776 & & 4.8747 & 4.4525 & $* * *$ \\
\hline Sad Score & 0.7262 & 0.6384 & & 0.4656 & 0.6598 & $* * *$ & 0.6019 & 0.6444 & & 0.3613 & 0.6623 & $* * *$ \\
\hline Pain Score & 1.1593 & 1.1657 & & 0.9082 & 1.1885 & $* * *$ & 1.5294 & 1.1596 & & 0.8287 & 1.1875 & $* * *$ \\
\hline Stress Score & 1.1520 & 0.9041 & $*$ & 0.7833 & 0.9313 & & 1.3024 & 0.9130 & & 0.7181 & 0.9323 & $* *$ \\
\hline
\end{tabular}

2010 and 2012 American Time Use Survey (ATUS) and its Well-being Modules (WBM). Number of observations is 3,475. Survey weights were used.

* Well-being score is statistically different across groups at the $90 \%$ confidence level

$* *$ Well-being score is statistically different across groups at the $95 \%$ confidence level

$* * *$ Well-being score is statistically different across groups at the $99 \%$ confidence level 
Table 3. Effects of Caregiving on Negative Well-being Measures

\begin{tabular}{|c|c|c|c|c|c|c|c|c|}
\hline \multirow{2}{*}{ Variables } & \multicolumn{2}{|l|}{ Tired } & \multicolumn{2}{|l|}{ Pain } & \multirow{2}{*}{$\begin{array}{c}\text { Sad } \\
\text { Coef. }\end{array}$} & \multicolumn{3}{|c|}{ Stress } \\
\hline & Coef. & Sig. & Coef. & Sig. & & Sig. & Coef. & Sig. \\
\hline \multicolumn{9}{|l|}{ Caregiving } \\
\hline \multirow[t]{2}{*}{ Care of HH Adults } & 0.3647 & & 2.9690 & $* * *$ & -0.0898 & & 1.9085 & $* * *$ \\
\hline & $(0.5488)$ & & $(0.1722)$ & & $(0.1139)$ & & $(0.3255)$ & \\
\hline \multirow[t]{2}{*}{ Care of Non-HH Adults } & 2.8094 & $* * *$ & -0.5024 & & 1.6805 & $* * *$ & 0.0160 & \\
\hline & $(0.2594)$ & & $(0.3167)$ & & $(0.0745)$ & & $(0.2764)$ & \\
\hline \multirow[t]{2}{*}{ Care of HH Children } & -0.7290 & & -0.6874 & & -0.1221 & & -0.0206 & \\
\hline & $(0.6511)$ & & $(0.5635)$ & & $(0.2999)$ & & $(0.3977)$ & \\
\hline \multirow[t]{2}{*}{ Care of Non-HH Children } & 2.1930 & $* * *$ & -0.6995 & $*$ & 1.5478 & $* * *$ & 2.1086 & $* * *$ \\
\hline & $(0.3080)$ & & $(0.3590)$ & & $(0.0780)$ & & $(0.1332)$ & \\
\hline \multirow[t]{2}{*}{ Age } & 0.0074 & & -0.0054 & & 0.0126 & $* * *$ & 0.0021 & \\
\hline & $(0.0061)$ & & $(0.0056)$ & & $(0.0043)$ & & $(0.0049)$ & \\
\hline \multirow[t]{2}{*}{ Female (vs. Male) } & 0.2493 & $* * *$ & 0.0816 & & 0.0161 & & 0.0753 & \\
\hline & $(0.0877)$ & & $(0.0797)$ & & $(0.0608)$ & & $(0.0699)$ & \\
\hline \multirow{2}{*}{ Married (vs. Unmarried) } & -0.1332 & & -0.2171 & $* *$ & -0.1414 & $*$ & -0.2486 & $* * *$ \\
\hline & $(0.1190)$ & & $(0.1002)$ & & $(0.0798)$ & & $(0.0869)$ & \\
\hline \multirow[t]{2}{*}{ White (vs. Non-White) } & 0.0829 & & -0.1197 & & -0.1583 & $*$ & 0.0047 & \\
\hline & $(0.1240)$ & & $(0.1207)$ & & $(0.0925)$ & & $(0.0981)$ & \\
\hline \multirow[t]{2}{*}{ Hispanic (vs. Non-Hispanic) } & -0.3741 & $*$ & 0.2656 & & 0.1675 & & 0.0181 & \\
\hline & $(0.2199)$ & & $(0.1759)$ & & $(0.1665)$ & & $(0.1593)$ & \\
\hline \multicolumn{9}{|l|}{$\begin{array}{l}\text { Education (vs. Less than High } \\
\text { School) }\end{array}$} \\
\hline \multirow[t]{2}{*}{ High School } & -0.4979 & $* * *$ & -0.0855 & & -0.3072 & $* * *$ & -0.2562 & $* *$ \\
\hline & $(0.1371)$ & & $(0.1318)$ & & $(0.0997)$ & & $(0.1156)$ & \\
\hline \multirow[t]{2}{*}{ Some College } & -0.4351 & $* * *$ & -0.2286 & $*$ & -0.2962 & $* * *$ & -0.1034 & \\
\hline & $(0.1446)$ & & $(0.1378)$ & & $(0.1037)$ & & $(0.1205)$ & \\
\hline \multirow[t]{2}{*}{ College } & -0.5585 & $* * *$ & -0.1733 & & -0.3234 & $* * *$ & -0.1797 & \\
\hline & $(0.1506)$ & & $(0.1494)$ & & $(0.1074)$ & & $(0.1302)$ & \\
\hline \multirow{2}{*}{ Advanced Education } & -0.4497 & $* * *$ & -0.3146 & $* *$ & -0.4255 & $* * *$ & -0.2926 & $* *$ \\
\hline & $(0.1677)$ & & $(0.1543)$ & & $(0.1208)$ & & $(0.1398)$ & \\
\hline \multicolumn{9}{|l|}{ Weekend diary day (vs. } \\
\hline \multirow[t]{2}{*}{ Weekday) } & -0.0419 & & 0.0048 & & -0.0130 & & -0.0558 & \\
\hline & $(0.0766)$ & & $(0.0718)$ & & $(0.0538)$ & & $(0.0586)$ & \\
\hline \multicolumn{9}{|l|}{ Number of Adult in the } \\
\hline \multirow[t]{2}{*}{ Household } & 0.1622 & $*$ & -0.0875 & & 0.0209 & & -0.0304 & \\
\hline & $(0.0918)$ & & $(0.0783)$ & & $(0.0584)$ & & $(0.0658)$ & \\
\hline \multirow{3}{*}{$\begin{array}{l}\text { Number of Children in the } \\
\text { Household }\end{array}$} & & & & & & & & \\
\hline & 0.2574 & & 0.3911 & $* *$ & 0.0812 & & 0.1518 & \\
\hline & $(0.1917)$ & & $(0.1813)$ & & $(0.1085)$ & & $(0.1228)$ & \\
\hline
\end{tabular}


2010 and 2012 American Time Use Survey (ATUS) and its Well-being Modules (WBM). Dummy variables for the year 2012 and for regions are included in all models but are not shown here. Standard errors are in parentheses. Survey weights are used. Number of observations $=3,475$.

* indicates significance at the $10 \%$ level. ** indicates significance at the $5 \%$ level. $* * *$ indicates significance at the $1 \%$ level. Instrumental variables are from Genworth 2010 and 2012 Cost of Care Survey, 2010 and 2012 Market Survey of Long-Term Care Costs, Health System Measurement Project, 2012 Across The States: Profiles of Long-Term Services and Supports, and 2014 Raising Expectations: A State Scorecard on Long-Tern Services and Supports for Older Adults, People with Physical Disabilities, and Family Caregivers. 
Table 4. Effects of Caregiving on Positive Well-Being Measures

\begin{tabular}{|c|c|c|c|c|}
\hline \multirow{2}{*}{ Variables } & \multirow{2}{*}{$\begin{array}{c}\text { Meaningful } \\
\text { Coef. }\end{array}$} & \multicolumn{3}{|c|}{ Нарру } \\
\hline & & Sig. & Coef. & Sig. \\
\hline \multicolumn{5}{|l|}{ Caregiving } \\
\hline \multirow[t]{2}{*}{ Care of HH Adults } & -2.0731 & $* * *$ & -1.4682 & \\
\hline & $(0.3597)$ & & $(0.9972)$ & \\
\hline \multirow[t]{2}{*}{ Care of Non-HH Adults } & -1.7396 & $* *$ & -2.1285 & $* * *$ \\
\hline & $(0.8592)$ & & $(0.1925)$ & \\
\hline \multirow[t]{2}{*}{ Care of HH Children } & 0.4823 & & 0.4216 & \\
\hline & $(0.6017)$ & & $(0.4795)$ & \\
\hline \multirow{2}{*}{ Care of Non-HH Children } & -1.9384 & $* * *$ & -1.6703 & $* * *$ \\
\hline & $(0.4652)$ & & $(0.3271)$ & \\
\hline \multirow[t]{2}{*}{ Age } & 0.0017 & & -0.0036 & \\
\hline & $(0.0057)$ & & $(0.0057)$ & \\
\hline \multirow[t]{2}{*}{ Female (vs. Male) } & 0.4359 & $* * *$ & 0.3227 & $* * *$ \\
\hline & $(0.0831)$ & & $(0.0827)$ & \\
\hline \multirow[t]{2}{*}{ Married (vs. Unmarried) } & 0.4227 & $* * *$ & 0.2064 & * \\
\hline & $(0.1045)$ & & $(0.1116)$ & \\
\hline \multirow[t]{2}{*}{ White (vs. Non-White) } & -0.0876 & & 0.0650 & \\
\hline & $(0.1231)$ & & $(0.1091)$ & \\
\hline \multirow[t]{2}{*}{ Hispanic (vs. Non-Hispanic) } & 0.5555 & $* * *$ & 0.4677 & $* * *$ \\
\hline & $(0.1694)$ & & $(0.1528)$ & \\
\hline
\end{tabular}

Education (vs. Less than High School)

$\begin{array}{lrr}\text { High School } & 0.1544 & 0.1152 \\ \text { Some College } & (0.1241) & (0.1201) \\ & 0.1407 & -0.0455 \\ \text { College } & (0.1367) & (0.1256) \\ & -0.1262 & -0.1563 \\ \text { Advanced Education } & (0.1434) & (0.1401) \\ & -0.0806 & 0.0034 \\ & (0.1645) & (0.1523) \\ \text { end diary day (vs. Weekday) } & -0.0595 & -0.0542 \\ & (0.0715) & (0.0673) \\ \text { er of Adult in the Household } & 0.0884 & 0.1418 \\ & (0.0795) & (0.0875)\end{array}$

Number of Children in the Household

$-0.2425 \quad-0.2038$

$(0.1496) \quad(0.1283)$

2010 and 2012 American Time Use Survey (ATUS) and its Well-being Modules (WBM). Dummy variables for the year 2012 and for regions are included in all models but are not shown here. Standard errors are in parentheses. Survey weights are used. Number of observations $=3,475$. 
* indicates significance at the $10 \%$ level. ** indicates significance at the $5 \%$ level. *** indicates significance at the $1 \%$ level. Instrumental variables are from Genworth 2010 and 2012 Cost of Care Survey, 2010 and 2012 Market Survey of Long-Term Care Costs, Health System Measurement Project, 2012 Across The States: Profiles of Long-Term Services and Supports, and 2014 Raising Expectations: A State Scorecard on Long-Tern Services and Supports for Older Adults, People with Physical Disabilities, and Family Caregivers. 
Table 5. Effects of Caregiving on Negative Well-Being Measures for All Individuals 50+

\begin{tabular}{|c|c|c|c|c|c|c|c|c|}
\hline \multirow{2}{*}{ Variables } & \multicolumn{2}{|l|}{ Tired } & \multicolumn{2}{|l|}{ Pain } & \multirow{2}{*}{$\begin{array}{c}\text { Sad } \\
\text { Coef. }\end{array}$} & \multicolumn{3}{|c|}{ Stress } \\
\hline & Coef. & Sig. & Coef. & Sig. & & Sig. & Coef. & Sig. \\
\hline \multicolumn{9}{|l|}{ Caregiving } \\
\hline \multirow[t]{2}{*}{ Care of HH Adults } & 0.4706 & & 2.4082 & $* * *$ & 1.2001 & & 0.2699 & \\
\hline & $(0.4322)$ & & $(0.1412)$ & & $(1.7421)$ & & $(0.2562)$ & \\
\hline \multirow[t]{2}{*}{ Care of Non-HH Adults } & 2.6068 & $* * *$ & 2.4145 & $* * *$ & 1.7743 & $* * *$ & 2.2914 & $* * *$ \\
\hline & $(0.2156)$ & & $(0.1062)$ & & $(0.1264)$ & & $(0.1120)$ & \\
\hline \multirow[t]{2}{*}{ Care of HH Children } & 0.3344 & & 0.0917 & & 0.5025 & $* *$ & 0.6797 & $*$ \\
\hline & $(0.2961)$ & & $(0.2290)$ & & $(0.1944)$ & & $(0.3601)$ & \\
\hline \multirow[t]{2}{*}{ Care of Non-HH Children } & 2.5016 & $* * *$ & -0.1913 & & 1.5590 & $* *$ & 2.1743 & $* * *$ \\
\hline & $(0.2241)$ & & $(0.2197)$ & & $(0.6257)$ & & $(0.1160)$ & \\
\hline \multirow[t]{2}{*}{ Age } & -0.0098 & $* *$ & -0.0007 & & 0.0021 & & -0.0066 & $*$ \\
\hline & $(0.0038)$ & & $(0.0038)$ & & $(0.0031)$ & & $(0.0035)$ & \\
\hline \multirow[t]{2}{*}{ Female (vs. Male) } & 0.1866 & $* * *$ & 0.0126 & & -0.0481 & & 0.0016 & \\
\hline & $(0.0544)$ & & $(0.0522)$ & & $(0.0463)$ & & $(0.0497)$ & \\
\hline \multirow{2}{*}{ Married (vs. Unmarried) } & -0.2781 & $* * *$ & -0.2972 & $* * *$ & -0.3072 & $* * *$ & -0.2431 & $* * *$ \\
\hline & $(0.0659)$ & & $(0.0619)$ & & $(0.0544)$ & & $(0.0587)$ & \\
\hline \multirow{2}{*}{ White (vs. Non-White) } & 0.1196 & $*$ & -0.1028 & & -0.0467 & & 0.0696 & \\
\hline & $(0.0713)$ & & $(0.0712)$ & & $(0.0563)$ & & $(0.0657)$ & \\
\hline \multirow[t]{2}{*}{ Hispanic (vs. Non-Hispanic) } & -0.2707 & $* *$ & 0.0399 & & 0.2364 & $* *$ & -0.0507 & \\
\hline & $(0.1100)$ & & $(0.1106)$ & & $(0.1036)$ & & $(0.0993)$ & \\
\hline \multirow{2}{*}{\multicolumn{9}{|c|}{$\begin{array}{l}\text { Education (vs. Less than High } \\
\text { School) }\end{array}$}} \\
\hline & & & & & & & & \\
\hline \multirow[t]{2}{*}{ High School } & -0.3712 & $* * *$ & -0.4890 & $* * *$ & -0.3468 & $* * *$ & -0.3287 & $* * *$ \\
\hline & $(0.0986)$ & & $(0.1021)$ & & $(0.0856)$ & & $(0.0933)$ & \\
\hline \multirow[t]{2}{*}{ Some College } & -0.4419 & $* * *$ & -0.5718 & $* * *$ & -0.3934 & $* * *$ & -0.2984 & $* * *$ \\
\hline & $(0.0993)$ & & $(0.1044)$ & & $(0.0872)$ & & $(0.0957)$ & \\
\hline \multirow[t]{2}{*}{ College } & -0.4985 & $* * *$ & -0.7478 & $* * *$ & -0.4189 & $* * *$ & -0.2296 & $* *$ \\
\hline & $(0.1050)$ & & $(0.1075)$ & & $(0.0899)$ & & $(0.1005)$ & \\
\hline \multirow[t]{2}{*}{ Advanced Education } & -0.3876 & $* * *$ & -0.7876 & $* * *$ & -0.4670 & $* * *$ & -0.1418 & \\
\hline & $(0.1107)$ & & $(0.1100)$ & & $(0.0940)$ & & $(0.1066)$ & \\
\hline \multicolumn{9}{|l|}{ Weekend diary day (vs. } \\
\hline \multirow[t]{2}{*}{ Weekday) } & -0.1833 & $* * *$ & 0.0133 & & -0.0786 & $*$ & -0.2999 & $* * *$ \\
\hline & $(0.0492)$ & & $(0.0470)$ & & $(0.0434)$ & & $(0.0433)$ & \\
\hline \multicolumn{9}{|l|}{ Number of Adult in the } \\
\hline \multirow[t]{2}{*}{ Household } & 0.0747 & $*$ & -0.0250 & & 0.0106 & & 0.0621 & \\
\hline & $(0.0432)$ & & $(0.0410)$ & & $(0.0761)$ & & $(0.0386)$ & \\
\hline Number of Children in the & & & & & & & & \\
\hline Household & 0.0265 & & 0.0054 & & -0.0831 & & -0.0519 & \\
\hline & $(0.0834)$ & & $(0.0672)$ & & $(0.0638)$ & & $(0.0925)$ & \\
\hline Retired (vs. Not-retired) & -0.3948 & $* * *$ & -0.1033 & & -0.1812 & $* * *$ & -0.4743 & $* * *$ \\
\hline & $(0.0745)$ & & $(0.0726)$ & & $(0.0535)$ & & $(0.0650)$ & \\
\hline
\end{tabular}


2010 and 2012 American Time Use Survey (ATUS) and its Well-being Modules (WBM). Samples are the age 50 and older. Number of observations $=9,082$. A dummy variable for the years 2012, and dummy variables for regions are included in all models but are not shown here. Standard errors are in parentheses. Survey weights are used. * indicates significance at the $10 \%$ level. ** indicates significance at the $5 \%$ level. $* * *$ indicates significance at the $1 \%$ level. Instrumental variables are from Genworth 2010 and 2012 Cost of Care Survey, 2010 and 2012 Market Survey of Long-Term Care Costs, Health System Measurement Project, 2012 Across The States: Profiles of Long-Term Services and Supports, and 2014 Raising Expectations: A State Scorecard on Long-Tern Services and Supports for Older Adults, People with Physical Disabilities, and Family Caregivers. 
Table 6. Effects of Caregiving on Positive Well-Being Measures for All Individuals 50+

\begin{tabular}{|c|c|c|c|c|}
\hline \multirow{2}{*}{ Variables } & \multirow{2}{*}{$\begin{array}{c}\text { Meaningful } \\
\text { Coef. }\end{array}$} & \multicolumn{3}{|c|}{ Hарру } \\
\hline & & Sig. & Coef. & Sig \\
\hline \multicolumn{5}{|l|}{ Caregiving } \\
\hline Care of HH Adults & $\begin{array}{l}-1.9489 \\
(0.2411)\end{array}$ & $* * *$ & $\begin{array}{r}-2.0099 \\
(0.1707)\end{array}$ & $* * *$ \\
\hline Care of Non-HH Adults & $\begin{array}{l}-1.9487 \\
(0.1844)\end{array}$ & $* * *$ & $\begin{array}{r}-2.0488 \\
(0.1406)\end{array}$ & $* * *$ \\
\hline Care of HH Children & $\begin{array}{l}-0.2565 \\
(0.2511)\end{array}$ & & $\begin{array}{r}0.1542 \\
(0.1852)\end{array}$ & \\
\hline Care of Non-HH Children & $\begin{array}{l}-1.4814 \\
(0.3329)\end{array}$ & $* * *$ & $\begin{array}{r}0.3524 \\
(0.9265)\end{array}$ & \\
\hline Age & $\begin{array}{r}0.0041 \\
(0.0036)\end{array}$ & & $\begin{array}{r}0.0123 \\
(0.0033)\end{array}$ & $* * *$ \\
\hline Female (vs. Male) & $\begin{array}{r}0.3547 \\
(0.0503)\end{array}$ & $* * *$ & $\begin{array}{r}0.2548 \\
(0.0541)\end{array}$ & $* * *$ \\
\hline Married (vs. Unmarried) & $\begin{array}{r}0.3227 \\
(0.0597)\end{array}$ & $* * *$ & $\begin{array}{r}0.2912 \\
(0.0626)\end{array}$ & $* * *$ \\
\hline White (vs. Non-White) & $\begin{array}{r}-0.2080 \\
(0.0677)\end{array}$ & $* * *$ & $\begin{array}{r}-0.1117 \\
(0.0646)\end{array}$ & $*$ \\
\hline Hispanic (vs. Non-Hispanic) & $\begin{array}{r}0.4744 \\
(0.0967)\end{array}$ & $* * *$ & $\begin{array}{r}0.2203 \\
(0.0953)\end{array}$ & $* *$ \\
\hline \multicolumn{5}{|l|}{ Education (vs. Less than High School) } \\
\hline High School & $\begin{array}{r}0.1240 \\
(0.0954)\end{array}$ & & $\begin{array}{r}0.0391 \\
(0.0898)\end{array}$ & \\
\hline Some College & $\begin{array}{r}0.1088 \\
(0.0954)\end{array}$ & & $\begin{array}{r}-0.0037 \\
(0.0893)\end{array}$ & \\
\hline College & $\begin{array}{r}-0.0971 \\
(0.1002)\end{array}$ & & $\begin{array}{r}-0.0659 \\
(0.0936)\end{array}$ & \\
\hline Advanced Education & $\begin{array}{r}-0.1058 \\
(0.1063)\end{array}$ & & $\begin{array}{r}-0.0632 \\
(0.0969)\end{array}$ & \\
\hline
\end{tabular}


2010 and 2012 American Time Use Survey (ATUS) and its Well-being Modules (WBM). Samples are the age 50 and older. Number of observations $=9,082$. A dummy variable for the years 2012, and dummy variables for regions are included in all models but are not shown here. Standard errors are in parentheses. Survey weights are used. * indicates significance at the $10 \%$ level. $* *$ indicates significance at the $5 \%$ level. *** indicates significance at the 1\% level. Instrumental variables are from Genworth 2010 and 2012 Cost of Care Survey, 2010 and 2012 Market Survey of Long-Term Care Costs, Health System Measurement Project, 2012 Across The States: Profiles of Long-Term Services and Supports, and 2014 Raising Expectations: A State Scorecard on Long-Tern Services and Supports for Older Adults, People with Physical Disabilities, and Family Caregivers. 
Appendix 
Table A1. Caregiving Probits for Tired Model

\begin{tabular}{|c|c|c|c|c|c|c|c|c|}
\hline \multirow[t]{2}{*}{ Model Variables } & \multicolumn{2}{|c|}{$\begin{array}{l}\text { Care of HH } \\
\text { Adults }\end{array}$} & \multicolumn{2}{|c|}{$\begin{array}{l}\text { Care of non- } \\
\text { HH Adults }\end{array}$} & \multicolumn{2}{|c|}{$\begin{array}{l}\text { Care of HH } \\
\text { Children }\end{array}$} & \multicolumn{2}{|c|}{$\begin{array}{l}\text { Care of non- } \\
\text { HH Children }\end{array}$} \\
\hline & Coef. & Sig. & Coef. & Sig. & Coef. & Sig. & Coef. & Sig. \\
\hline Age & 0.0102 & & -0.0148 & $* * *$ & -0.0242 & ** & -0.0176 & *** \\
\hline Female & 0.2161 & ** & -0.1323 & ** & -0.0620 & & 0.0419 & \\
\hline Married & 0.6881 & $* * *$ & -0.0908 & & 0.0633 & & 0.3958 & $* * *$ \\
\hline White & -0.1958 & & 0.1350 & & 0.2168 & & -0.0179 & \\
\hline Hispanic & -0.0574 & & -0.0474 & & 0.4779 & & 0.3815 & $* *$ \\
\hline \multicolumn{9}{|l|}{ Education (vs. Less than High School) } \\
\hline High school & -0.0579 & & 0.2812 & $* * *$ & 0.4939 & * & 0.1862 & \\
\hline Some college & -0.0171 & & 0.4020 & $* * *$ & 0.8302 & $* * *$ & -0.0452 & \\
\hline College & -0.2687 & & 0.2025 & $*$ & 0.4402 & & 0.2457 & * \\
\hline Advanced education & -0.0112 & & 0.2775 & $* *$ & 0.6120 & $*$ & 0.2288 & \\
\hline \multicolumn{9}{|l|}{ Region (vs. West) } \\
\hline Northeast & 1.2904 & $* *$ & 1.2010 & $* * *$ & 0.2399 & & -0.3182 & \\
\hline Midwest & 0.8813 & $* *$ & 0.7526 & $* * *$ & 0.8942 & & -0.6290 & ** \\
\hline South & 0.7548 & $*$ & 0.1099 & & 1.9634 & $* * *$ & -0.4665 & $*$ \\
\hline Yr 2012 & 0.4347 & $* * *$ & 0.1768 & $* *$ & 0.4620 & $* *$ & -0.0552 & \\
\hline Weekend & -0.0461 & & -0.0197 & & -0.1708 & & -0.1399 & $*$ \\
\hline Number of adults in the household & 0.3434 & $* * *$ & -0.0920 & & -0.3964 & $* * *$ & -0.2563 & $* * *$ \\
\hline Number of children in the household & -0.4479 & $* *$ & -0.0377 & & 1.6872 & $* * *$ & -0.0810 & \\
\hline \multicolumn{9}{|l|}{ Instrumental variables } \\
\hline \multicolumn{9}{|l|}{ By Year and State: } \\
\hline Assisted Living Facility Annual Rate (in $\$ 1,000$ ) & -0.0484 & $* * *$ & -0.0156 & $*$ & 0.0364 & $*$ & -0.0037 & \\
\hline Nursing Home Annual Rate (Private Room) (in $\$ 1,000$ ) & -0.0099 & & $\begin{array}{r}-0.0052 \\
45.132\end{array}$ & & $\begin{array}{r}-0.0660 \\
159.100\end{array}$ & $* * *$ & -0.0226 & $* * *$ \\
\hline Home Health Aide Services Hourly Rate (in $\$ 1,000$ ) & -7.3244 & & 2 & ** & 9 & ** & -0.2421 & \\
\hline Adult Day Services Daily Rate (in $\$ 1,000$ ) & -0.0111 & & -1.2658 & & 17.2573 & $* *$ & 2.1730 & \\
\hline $\begin{array}{l}\text { By Year and Region: } \\
\text { Percent of People with at Least One Activities of Daily Living }\end{array}$ & & & & & & & & \\
\hline ( & $\begin{array}{l}1.1042 \\
28\end{array}$ & & 2.7445 & $* *$ & -7.4198 & & -2.2871 & \\
\hline
\end{tabular}


By State:

Nursing Facility Service Expenditure (in $\$ 1,000$ )

Total Administration for Community Living (ACL) Congregate and Home Delivered Meal Expenditures (in billions of \$)

Median Hourly Wage of Personal and Home Care Aides (in

$\$ 1,000)$

Percent of People Age 75 and Above Living Alone

Percent of People Age 65 and Above Households with Someone under 18

Percent of Residents with Medicare as Primary Payer

Percent of Nursing Facilities Visited by Ombudsman at Least Quarterly

State Ranking on Long-Term Services and Supports (LTSS)

System Performance (1-51 range)

Ratio of the Economic Value of Family Caregiving to Medicaid

Long-Term Care Spending

Number of Private Long-Term Care Insurance Policies in Effect,

per 1000 Age 40 and Above

Number of Participants in Personal Care Services (PCS) and

Home Health, per 1,000

Number of Assisted Living and Residential Care Facilities, per

1000 Age 65 and Above

Number of People Receiving the Administration for Community

Living (ACL) Congregate Meals

Number of People Receiving Administration for Community

Living (ACL) Home Delivered Meals

RN hours per day

\begin{tabular}{|c|c|c|c|c|c|c|c|}
\hline-0.0551 & $* *$ & -0.0334 & $* * *$ & 0.0429 & & 0.0124 & \\
\hline-18.1631 & * & -9.2068 & $* *$ & 28.0324 & $* *$ & 4.3176 & \\
\hline 0.3396 & $*$ & -0.0598 & & -0.1838 & & 0.2239 & $*$ \\
\hline 0.0114 & & 0.0391 & & -0.1684 & $*$ & 0.0618 & \\
\hline 0.1612 & $*$ & 0.1541 & $* * *$ & -0.0247 & & -0.0640 & \\
\hline-0.0017 & & 0.0577 & $* *$ & -0.1632 & $*$ & 0.0961 & $* *$ \\
\hline-0.0054 & & 0.0030 & & 0.0075 & & -0.0040 & \\
\hline-0.0328 & $* * *$ & 0.0037 & & 0.0098 & & 0.0029 & \\
\hline-0.0967 & & -0.0809 & $* *$ & -0.1665 & & -0.0658 & \\
\hline-0.0389 & $* * *$ & -0.0004 & & -0.0263 & $* * *$ & 0.0023 & \\
\hline-0.0682 & $* *$ & -0.0415 & $* * *$ & 0.0743 & & 0.0300 & \\
\hline-0.1542 & $* * *$ & -0.0424 & & 0.0047 & & -0.0266 & \\
\hline 0.0091 & $* *$ & 0.0039 & $*$ & -0.0242 & $* * *$ & -0.0047 & \\
\hline-0.0014 & & 0.0029 & & -0.0178 & & -0.0085 & \\
\hline 2.5043 & $*$ & 1.2118 & $*$ & 8.2421 & $* * *$ & -1.4020 & \\
\hline
\end{tabular}

Prob $>$ F

0.1455

2010 and 2012 American Time Use Survey (ATUS) and its Well-being Modules (WBM). Instrumental variables are from Genworth 2010 and 2012 Cost of Care Survey, 2010 and 2012 Market Survey of Long-Term Care Costs, Health System Measurement Project, 2012 Across The

States: Profiles of Long-Term Services and Supports, and 2014 Raising Expectations: A State Scorecard on Long-Term Services and Supports for Older Adults, People with Physical Disabilities, and Family Caregivers. Number of observations $=3,475$. * indicates significance at the $10 \%$ level.

$* *$ indicates significance at the $5 \%$ level. $* * *$ indicates significance at the $1 \%$ level. Survey weights were used.

The other caregiving probit models are available upon request. 